Izvorni članak UDK 101:2Zimmerman, S. doi: $\underline{10.21464 / \text { fi36109 }}$ Primljeno 15.1.2016.

\title{
Zvonko Miličić
}

Franjevačka klasična gimnazija, Bosne Srebrene 4, BA-71300 Visoko zvonemilicic@hotmail.com

\section{Stjepan Zimmermann: Temelji (prijekantovske) filozofije}

\begin{abstract}
Sažetak
Premda se Stjepan Zimmermann cijeloga života bavio noetičkom problematikom, u ovome se prilogu-polazeći od njegova djela Temelji filozofije iz 1934. - pokušava odgovoriti na pitanje: Što Zimmermann uopće podrazumijeva pod »filozofijom«, koji su njezini »temelji«, »smisao" i krajnji dosezi? Unatoč pokušaju da filozofiju utemelji »noetički«, on ne ide povrh njezinoga skolastičko-neoskolastičkoga razumijevanja kao »teodiceje«, kao opravdanja Boga u povijesti, što nije posao teologije, nego filozofije.
\end{abstract}

\section{Ključne riječi}

»stvar po sebi«, Bog, vjera, filozofska vjera, transcendencija, egzistencija, suvremena filozofija egzistencije, neoskolastika

\section{Uvod: »Kantov promašaj cilja«?}

Za uvod u danu problematiku namjerno smo uzeli naslov jednoga članka pokojnoga Rudolfa Brajičića, dugogodišnjega profesora na Filozofskome fakultetu Družbe Isusove u Zagrebu, ${ }^{1}$ s obzirom na to da on možda najslikovitije dočarava odnos cjelokupne neoskolastike prema Kantu. Razlog tome relativno je jednostavan: Kantovo nijekanje mogućnosti spoznatljivosti »stvari po sebi« i zadržavanje ideje Boga u sferi praktičnoga uma isključivo kao »regulativne ideje« za čovjekovo moralno djelovanje (kategorički imperativ) izravno udara na cjelokupnu dotadašnju metafiziku i teologiju (ontoteologiju u smislu M. Heideggera) koja je smatrala da svojim »prelijetanjem« (überfliegen) granica zbiljskoga i mogućega iskustva može "posredovati« posljednje božanske istine i time za sebe osigurati trajni monopol na njihovo izricanje $\mathrm{i}$ prevođenje u moralne imperative kršćanskoga »krjeposnog života«.

Koji su sada Kantovi transcendentalno-teorijski razlozi, zbog kojih »ideju Boga« smješta u sferu praktičnoga uma?

Usp. Brajičić: 1995, 950-959. Kant je po Zimmermannu, prvo, radikalno doveo u pitanje mogućnost objektivnosti ljudske spoznaje (adequatio rei et intellectus); drugo, mogućnost spoznaje »izvansvjesne egzistencije«, pa tako i spoznaje Boga, što zagovara skolastičko-neoskolastički noetički realizam; i treće, kauzalnu metafiziku koja zagovara ideju Boga kao »sveuzrokojućega« i istodobno »neprouzročenoga uzroka«, »u koliko je naime stavio [...] uvjete za mogućnost znanstvenog iskustva isključivo u ljudsku svijest - logičkom je nuždom otuda izveo princip o vrijednosti naše spoznaje« (Zimmermann: 1921, 105). Usp. o tomu također Kusić: 2002, 5 i dalje. 
Prvi je svakako Kantov »kopernikanski obrat«, tj. uvid da se konstitucija fenomenalnoga, osjetilno danog svijeta događa isključivo u sferi »transcendentalnih funkcija subjektivnosti«, u sferi onoga osjetilno danog koje se kao takvo čini naknadnim predmetom tzv. »transcendentalne sinteze«, tako da više nije bitno što predmet sam po sebi jest, nego samo to na koji ga način taj transcendentalni subjekt sintetizira u svojoj svijesti i time konstituira kao takvoga ili, rečeno s Hegelom: ono »po sebi« postoji samo kao »za mene« (für mich). Osjetilna kauzalnost konstitucije predmetnoga svijeta otuda nikada ne može sama iz sebe proizvesti onu vrstu metafizičke kauzalnosti kojom je Aristotel zaključio na "prvo pokretalo«, što je po Kantu ne samo nedopustivo, nego i neobrazloživo. Nedopustiv je također i Anzelmov »ontološki dokaz o Bogu« zato što

»... je pojam nekoga apsolutno nužnog bića jedan čisti pojam uma, tj. jedna čista ideja, čija objektivna realnost uopće još nije dokazana time što je um treba, koja također daje samo uputu na izvjesnu, premda nedostižnu potpunost, te uistinu više služi za to da se ograniči razum nego da se proširi na nove predmete. Ovdje se sada susreće nešto začuđujuće i protusmisleno, to da se zaključak od nekoga danog opstanka uopće na bilo koji čisto nužni opstanak čini nužnim i mi također protiv sebe imamo sve uvjete razuma da se [čisto nužni opstanak - Z. M.] učini pojmom te nužnosti. $\ll^{2}$

U slučaju govora o nekom »apsolutno nužnom biću« Bogu, radi se o onoj vrsti »bezvremene« dedukcije čistih pojmova koji ne stoje ni u kakvoj korelaciji s onim čiji su oni pojmovi, zbog čega oni, prema Kantu, ostaju prema neposrednoj osjetilnoj zbiljnosti »slijepi«, a po svom unutarnjem sadržaju »prazni«, čiste umne konstrukcije bez ikakvoga sadržajnog uporišta. »Čisti um«, koji prelijeće granice toga iskustva i time se zapleće u »antinomije«, potpuno je izvan prostora i vremena kao apriornih uvjeta zornosti, odnosno iskustva uopće, tako da »mogući predmet« spoznaje može biti dan sam unutar tih formi zora. ${ }^{3}$ Upravo zbog toga bi svaki, bilo metafizički ili teološki »govor o Bogu«, svodio samoga Boga - upravo putem jezika - unutar granica prostorno vremenske danosti (zornosti), time bi se Boga činilo pukim bićem među drugim bićima koje bi sada bilo imanentno svakoj spoznavajućoj svijesti i time ukinuto u svojoj transcendentnosti.

Kako bi izbjegao taj predmetni odnos prema Bogu i s druge strane opravdao svoj »kategorički imperativ«, Kant u izvođenju »fiziko-teološkoga dokaza» navodi razloge zbog koji se na temelju toga dokaza smije zaključiti na božansku mudrost i dobrotu. Prema Kantu, »najviše je dobro u svijetu moguće samo ako se pretpostavi najviši uzrok prirode« (Kant: KdrV, 225), tj. s obzirom na to da najviši uzrok prirode (Boga) ne možemo izvesti iz iskustva, nužno je da ga se pretpostavi, čime sâm Kant (naime upravo s tom »pretpostavkom《) zapada u teškoće ontološkoga dokaza Boga uopće ne pokušavajući dokazati njegovu egzistenciju, nego polazi od nje kao one »pretpostavke« koja sada ima moralnu funkciju u smislu Leibnizova dokazivanja ovoga svijeta kao »najbolje mogućega«:

»Dosljedno je postulat mogućnosti najvišega izvedenog Dobra (najboljega svijeta) ujedno postulat zbiljnosti najvišega izvornog Dobra, naime egzistencije Boga.«4

To jest, sam bitak mora se pretpostaviti kao »realni predikat« zato što bi tada - upravo s gledišta praktičnoga uma - bilo nemoguće izvesti bilo kakvo »trebanje« (Sollen) ili bilo kakav imperativ, što za Kanta opet samo znači to da je »moralno nužno pretpostaviti postojanje Boga« (Kant: KdpV, 226).

Bog, drugim riječima, Kantu treba kao posljednja instancija valjanosti našega praktičnog (moralnog) djelovanja, pri čemu jasno naglašava njegovu nespo- 
znatljivost. Međutim, ta »nespoznatljivost« iziskuje »vjeru« koja po sebi ne može izdržati sud »čistoga razuma«, tako da Kantu - čini se - nedostaje ona »nad-instancija« moralne prosudbe koju su svojom komunikativnom pragmatikom i teorijom intersubjektivnosti pokušali riješiti Apel i Habermas.

Cjeloživotna tema S. Zimmermanna bila je spoznajna teorija ili, kako je sam volio reći, »noetika «, ${ }^{5}$ prema staroj neoskolastičkoj podjeli filozofskih znanosti u kojoj se razlikuju »kritika« i »noetika« - podjela kakvu je, na tragu Christiana Wolffa, u svom filozofskom sustavu uvažavao već prvi vrhbosanski nadbiskup Josip Stadler. ${ }^{6}$ U ovoj svezi ne zanima nas Zimmermannovo shvaćanje noetike i ne zanima nas njegova kritika Kanta, ${ }^{7}$ nego prvenstveno pitanje: Što Zimmermann uopće podrazumijeva pod filozofijom i je li takvo razumijevanje uopće sukladno suvremenom samorazumijevanju filozofije? S takvim se pitanjem izravno usmjeravamo na Zimmermannovo djelo Temelji filozofije iz 1934. godine.

\section{Zimmermannovo »noetičko« shvaćanje bîti filozofije}

Prema Zimmermannu, filozofija se od drugih znanosti razlikuje po tome što nastoji shvatiti »cjelovitost svega što postoji« (Zimmermann: TF, 3). To, dakako, svaka iz svojega kuta, nastoje shvatiti i sve druge znanosti, tako da se na prvi pogled ne nazire njihova differentia specifica. Nju Zimmermann, u duhu suvremene filozofije egzistencije, nalazi u tome što filozofija nastoji dokučiti »puni smisao« čovjekova života. Isto to nastoji i teologija te se sada postavlja opravdano pitanje o njihovom međusobnom odnosu, tj. o njihovim bitnim polazištima $\mathrm{i}$ isto tako bitnim razlikama.

Odgonetajući »sfingu svijeta«, svijeta u cjelini, prema Zimmermannu čovjek dolazi do temeljnoga pitanja o postojanju Boga, čime odmah problem prebacuje u sferu religijskoga i jasno naglašava prvenstvo religijske pred fi-

Kant: KdrV, B 620. Za Kanta bi to značilo, smjeli bismo interpretirati, ponovni pad $\mathrm{u}$ onu vrstu platonizma i neoskolastike Anzelmova tipa koja smatra da (apsolutni) pojam prethodi konkretnome sadržaju (Hegel), da ideja kao mogućnost prethodi zbiljnosti (Husserl), a da um prethodi svijetu iz kojega je uopće i nastao.

»Pojam nekoga mogućeg predmeta spoznaje uopće, kakav proizlazi ujedno s pojmom moguće spoznaje (u transcendentalnoj refleksiji o tom pojmu), jest Kantov pojam 'transcendentalnoga predmeta'. Tom pojmu ne pripadaju 'obilježja' bilo kojega posebnog predmeta, nego samo 'obilježja' (djelomični pojmovi) toga pojma koji uopće dopušta da se kao moguć pojavi neki spoznatljivi predmet.« (Simon: 1974, 9-10)

4

Kant: KdpV, 226. Kritizirajući taj stari fiziko-teološki argument Kant dalje obrazlaže: »Nakon što se dospjelo do divljenja veličini i mudrosti, moći etc. Stvoritelja i ne može se ići dalje, odjednom se napušta argument izveden iz empirijskih dokaza i ide se na slučajnost koja je već na početku zaključena na temelju reda i svrhovitosti. Od te se slučajnosti, jedino putem transcendentalnih pojmova, sada ide k postojanju nečega čisto nužnoga, a od pojma apsolutne nužnosti prvoga uzroka ide se k njegovom sasvim određenom ili određujućem pojmu, naime k pojmu sveobuhvatne realnosti. Fiziko-teološki dokaz ostao je, dakle, skriven u svom poduhvatu, tj. u toj je nevolji iznenada napravio preskok ka kozmološkom dokazu i budući da je ovaj samo skriveni ontološki dokaz, one je svoju namjeru doista proveo samo kroz čisti um, neovisno o tome što je odmah na početku porekao svaku srodnost s njim i sve zasnovao na očiglednim dokazima iz iskustva.« (Kant: KdrV, B 657)

Usp. o tomu posebice Kusić: 2002, 1 i dalje.

6

Usp. o tomu posebice Josipović: 2010, 15 i dalje; Pavić: 2006, 35 i dalje.

Osim Čehokovih razmatranja o Kantu (Čehok: 1993, 1995) od novijih studija s neoskolastičke pozicije usp. posebice Lovrić: 2014. 
lozofskom sviješću: filozofija ne može biti bespretpostavna jer ukoliko želi odgovoriti na pitanje o konačnome smislu egzistencije, što je za Zimmermanna kao kršćanina, jasno, Bog, utoliko je, za njega posve razumljivo, neprihvatljiva svaka ona postavka koja započinje iz same sebe (Hegel, Fichte) ili iz vlastite egzistencije (Heidegger, Jaspers). U svojemu razumijevanju filozofije, Zimmermann postupa izričito aksiomatski, razlikujući religiju u subjektivnom (postoji li Bog u čovjekovoj svijesti) i religiju u objektivnom smislu:

»Izrazom 'Bog' pomišljamo biće, koje nužno postoji (egzistira), koje svojom egzistencijom nije ni u kome odnosu (relaciji) ovisnosti, koje dakle nije relativno, nego apsolutno. Osim toga, ovo biće pomišljamo da nije bez razuma i volje, tj. osobno biće. Iz ove dvije konstitutivne oznake u pojmu Boga izvire i treća, da je Bog ljudske živote razumno i voljno sa sobom povezao. Ovu vezu između Boga i čovjeka, koliko su zajednički objekt našeg poimanja, zovemo religija $u$ objektivnom smislu.« (Zimmermann: TF, 247)

Kao što ćemo vidjeti, ovo razlikovanje »subjektivne« i »objektivne« religije Zimmermannu je potrebno za kasnije razgraničenje filozofije i teologije $u$ duhu Tomina shvaćanja »dva kata istine«.

Drugo, Zimmermann razmatra pitanje o znanstvenosti filozofije, koje je početkom XX. stoljeća postavio već Edmund Husserl u svojem glavnom kasnom djelu Filozofija kao stroga znanost ${ }^{8}$ i utvrđuje kriterije znanstvenosti: »da ima zasebni svoj predmet ili objekt (tj. ono čim se bavi), i 2. da svoj predmet nastoji upoznati na znanstven način« (Zimmermann: TF, 230): dok se druge pojedinačne znanosti bave »prirodom« (fizika), živućim i njegovim zakonitostima (biologija), idealnim geometrijskim likovima i brojčanim odnosima, duševnim stanjima i procesima (psihologija), filozofija za »predmet« ima cjelokupno područje realnoga i idealnoga bitka, ali s onu stranu naših pukih »mnijenja« ili »predrasuda« o tom bitku (Aristotel, Husserl). Svojom usmjerenošću na »spoznaju istine« filozofija je nužno upućena na »noetiku«, a to je ono što je bitno razlikuje od svih drugih znanosti i što joj prema Zimmermannu također daje za pravo da prosuđuje svaku drugu znanost. ${ }^{9}$ Ovdje se sada postavlja ono staro pilatovsko pitanje: »Što je istina?«

Zanimljivo je primijetiti da Tomina skolastika i općenito neoskolastika u cjelini, a s njom i Zimmermann, odustaju od onog Kristovog »Ja sam put, istina i život« (Iv 14,6) i umjesto toga u filozofiji zagovaraju mogućnost potpuno adekvatne spoznaje, odnosno parmenidovski identitet mišljenja i bitka, zbog čega »noetika« ima prvenstvo i pred egzistencijalno shvaćenom vjerom zato što se pravo »opravdanje« vjere događa noetički, a ne vjerom samom koja u konačnici može biti potpuno ravnodušna prema tom racionalnom opravdanju.

»Noetička metodika«, koja prema Zimmermannu treba biti jamac znanstvenosti filozofije, gradi se na pretpostavci $» d a$ je razum zavisan od predmetâ, $\mathrm{i}$ prema tome da vrijednost spoznaje sastoji u skladu s predmetima« (Zimmermann: TF, 221-222), što znači da predmet određuje uvjete njegova spoznavanja u svojoj danoj situaciji, a ne da se - kao kod Kanta - svodi u okvire apriornih formi zornosti i onda naknadno konstituira kao takav. Tako (adekvatno) spoznati predmet svoju istinu dobiva u »sudu« koji može biti trostruko »osiguran«: metafizički (»Cjelina je veća nego dio.«), fizički (»Ova bi knjiga bez potpore pala na zemlju.«) i moralni (»Majke ne truju svoju djecu. «). ${ }^{10}$ Mjesto događanja istine upravo je »sud « kojim mišljenje izriče nešto o predmetu polazeći od njega samoga, tako da u tom neoskolastičkom shvaćanju suđenje nije - nasuprot Kantu - plod produktivnosti (spontanosti) razuma, nego čin puke receptivnosti u kojemu - paradoksalno rečeno - objekt kroz spoznajni subjekt izriče samoga sebe i odnosi se kroz njega prema sebi samome, tako da 
»subjekt« u tom smislu zapravo i ne postoji, nego je puko sredstvo samoizricanja objekta, čime istodobno gubi svoja individualna, faktično-egzistencijalna obilježja, tj. u korist »objekta« sam se srozava na razinu objekta. Ta je teza, gledano noetički, potpuno nespasiva zato što bi u tom pogledu spoznavajući subjekt izgubio sva individualno-kontingentna svojstva, a time onda

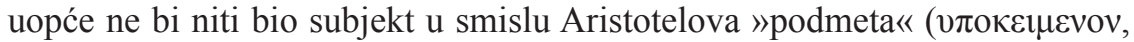
subiectum). No situacija se radikalno mijenja kada umjesto spoznajno-teorijske relacije između subjekta i objekta uvedemo odnos Bližnjega i Bližnjega, pri čemu se kao »Bližnji« shvaćaju Drugi, sva bića u svijetu i Bog. Naime, u toj situaciji »blizine«, kao što je to davno istaknuo Eugen Fink, a do radikalnosti doveo Emmanuel Levinas u svojoj filozofiji »nedodirljivog Drugog«, ono najdalje postaje najbliže, prestaje biti ono "nepoznato« i »prijeteće» (Heidegger). Upravo zbog toga valjalo bi - nasuprot Zimmermannu - pokazati da u temelju filozofije ne počiva nikakva, samoj sebi dostatna »noetika«, nego prije svega iskustvo bližnjega, ne kao pukoga »predmeta« ili »objekta« spoznavanja i istodobno raspolaganja, nego kao ono što nam se, u Jaspersovu smislu, pojavljuje kao »šifra«, kao uputa na ono »obuhvatno« (das Umgreifende) naše vlastite egzistencije, u odnosu na što u vodu pada svaki »predmetni« odnos skolastičko-neoskolastičkoga tipa.

Destruirajući aristotelovsko-tomističko shvaćanje istine kao slaganja mišljenja i bića u sudu, Martin Heidegger pokazuje da ni biće koje se spoznaje ni onaj koji spoznaje, ni sud ne mogu biti neovisni o Kako, odnosno o »situaciji« u kojoj, s obzirom na to da su i jedan i drugi smješteni »u« svijetu, spoznavanje i suđenje ne mogu se odvijati nikako izvan toga »u«, tako da - upravo polazeći od kontingentnoga statusa spoznavajućeg i spoznatog - nikada ne možemo govoriti o nekoj »adekvatnosti« (objektivnosti) spoznaje, nego samo o trenutačnoj perspektivi iz koje nam se dano biće otkriva kao takvo. Zbog toga je svaki sud koliko otkrivajući toliko još više skrivajući, ${ }^{11}$ iz čega Heidegger onda s Heraklitom izvodi svoje razumijevanje istine kao »neskrivenosti« (Unverborgenheit).

Zimmermannu je potpuno strana misao o »Kako« otkrivenosti nekoga predmeta jer se njegova konstitucija izvodi jedino polazeći od idealnih uvjeta for-

Usp. Husserl: Hua VI; Pažanin: 1968.

»Prirodne znanosti ispituju zakone materijalnog bitka, istražuju uzroke prirodnih pojava; pri tom poslu već pretpostavljaju poznate pojmove o bitku, uzroku, zakonu itd. O tim najopćenitijim pojmovima raspravlja ontologija. I ona dakle spada u okvir filozofije. Bez filozofije nemaju druge znanosti niti svoje pojmove niti svoje kritičko opravdanje. Noetika prethodi i ontologiji utoliko, što i ontološki pojmovi dobivaju vrijednost tek po kritičkom ispitivanju znanja« (Zimmermann: TF, 233), na temelju čega bi paradoksalno proizlazilo da mišljenje prethodi bitku kao u slučaju Descartesovog »Cogito, ergo sum«.

10

»Kod prvoga [metafizičkog suda - Z. M.] da bi protivurječno bilo tvrditi 'dio je veći od cjeline'; jer tko zna što znači 'dio' a što znači 'cjelina', zna također, da se već samom značenju tih riječi protivi tvrditi 'dio je veći od cjeline'. Prvi je dakle sud bezuvjetno i apsolutno nuždan. Drugi i treći nije bezuvjetno, nego je uvjetno (hipotetički) nuždan. Jer ova knjiga kao i svako tijelo mora da padne na zemlju samo ukoliko postoji fizički zakon privlačivosti zemlje; a moralni zakon ili prirođena majčina ljubav jest uvjet za nužnost trećega suda.« (TF 58)

11

»Iskaz je istinit, znači: on otkriva biće na njemu samome. On iskazuje, on pokazuje,

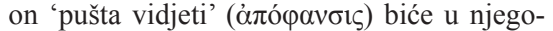
voj otkrivenosti. Biti istinit (istinitost) iskaza mora se razumjeti kao biti-otkrivajući. Dakle, istinitost uopće nema strukturu nekoga slaganja između spoznavanja i predmeta u smislu prilagodbe jednoga bića (subjekta) nekom drugom (objekt). Biti-istinit kao biti-otkrivajući opet je ontološki moguće samo na temelju bitka-u-svijetu. Taj fenomen, u kojemu smo spoznali temeljno ustrojstvo tubitka, jest fundament izvornoga fenomena istinitosti.« (Heidegger: 1984, 218-219) 
malno-logičkoga suđenja, čime se, kao što pokazuje Heidegger, sam bitak bića reducira na logičku (afirmativnu) kopulu »jest«. No Zimmermann ipak s Augustinom i Descartesom tvrdi »da je vlastita egzistencija prva nesumnjiva istina « (Zimmermann: TF, 60), pritom dakako potpuno odbacujući njezinu faktičnu situaciju, bez koje spoznavajući i sudeći subjekt može biti potpuno ravnodušan prema spoznatome biću: on ga nikada ne iskušava na način njegove »značajnosti« (Bedeutsamkeit) za vlastitu egzistenciju, nego kao puki "predmet« izricanja - njega ne zanima »Bližnji«, nego predmet u sudu, ${ }^{12}$ zbog čega kod njega noetika ima prvenstvo ne samo pred ontologijom nego i etikom:

»Od nje [noetike - Z. M.] su zavisne sve druge znanosti. Jer svaka znanost je znanost u suvislu cjelinu (sustavno) složeno znanje, stečeno i obrazloženo istraživalačkim putovima (metodama) - sa ciljem da upozna istinu. A nikoja znanost, osim noetike, ne stavlja sebi u zadatak da upozna istinu - o istini: na čemu je moguće i na čemu se osniva i o čemu je moguće istinito znanje.« (Zimmermann: TF, 4-5)

\section{2. »Metempirički« korijeni filozofije i »teodicejska« zadaća filozofije}

»Metempiričko« služi kod Zimmermanna kao istoznačnica za Aristotelov pojam »metafizika«, što on u oba slučaja prevodi kao "prekoskustveno«, »nadiskustveno« itd., i po njemu filozofija uopće nema zadaću da u smislu suvremene filozofije »prevlada« tu metafiziku, primjerice vraćajući se u područje egzistencije (Heidegger) ili ostajući u sferi »mogućega i zbiljskoga«, osjetilnog iskustva (Kant) i subjektivnih transcendentalnih postignuća (Kant, Husserl). Naprotiv, prema Zimmermannu, filozofija se upravo mora graditi na tom »metempiričkom « iskustvu, što u njegovu slučaju znači na »vjeri«, čime se vjera postavlja kao temelj valjanosti svake filozofske spoznaje. Mogli bismo odmah prigovoriti: takva filozofija, zasnovana na vjeri, izbjegava svaku vrstu »verifikacije«, bilo putem »empirijske«, »intersubjektivne« ili koje druge vrste kritičke provjere. Na taj prigovor Zimmermann odgovara:

»Samo neznalački, bez dodira s naukom, mogao bi tko ustvrditi, da je izvor metafizičkih pitanja u kršćanstvu, i da su odgovori na ta pitanja nošeni autoritetom kršćanskog vjerovanja. Tko to tvrdi, izgubio je spoznaju historijske činjenice, da se već u pretkršćanskoj davnini metafizički duh grčke filozofije nastojao primaknuti nepojavnim izvorima svijeta i života.« (Zimmermann: $\mathrm{TF}, 8)$

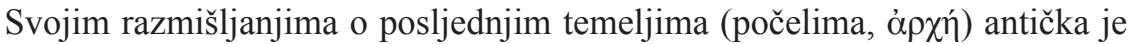
filozofija uvijek dolazila do onih »graničnih situacija» (Grenzsituationen) koje su je dovodile u kušnju metafizičkoga prelijetanja granica iskustva i govora o Bogu iz sfere imanencije, no to je karakteristika cjelokupne povijesti filozofije, o čemu svjedoči izvrsna dvosveščana knjiga Wilhelma Weischedela Gott der Philosophen (Weischedel: 1972). Drugo, Zimmermann potpuno prešućuje činjenicu da je Toma Akvinski izvršio »transpoziciju« cjelokupne Aristotelove filozofije $\mathrm{u}$ »teodiceju « (naravno bogoslovlje) i još je više ugradio u čitavu zgradu svojih teoloških suma, tako da nam se današnje kršćanstvo očituje u tom aristotelovsko-tomističkom stavu službene Crkve. Treće, metafizika svoj »zarodak« (da upotrijebimo Zimmermannov izraz) svakako nema u kršćanstvu, ali je kršćanstvo upravo adoptiralo grčku duhovnost, a time i sve probleme koji proistječu iz antičke filozofije. ${ }^{13}$ Upravo zbog toga Zimmermann želi izvršiti razgraničenje »između metafizičke filozofije i religije«, odnosno teologije. 
Kada promatramo sve stvoreno u svijetu, nužno spoznajemo njegovu prolaznost, propadljivost, nestalnost, naprosto vremenitost. U pogledu te spoznaje, na što cijelo vrijeme upozorava ne samo kršćanstvo nego i suvremena filozofija egzistencije, iz čega su npr. Heidegger i Gadamer u ontološkom smislu izveli »bit hermeneutičkoga iskustva«, Zimmermannu se ne postavlja filozofsko, nego prije svega teološko pitanje:

»... da li je moguće da egzistiraju samo relativna bića, ili moramo kazati, da egzistira i nešto što nije 'relativno', što se ne nalazi u relaciji uzročnosti, tj. što ne egzistira s nekim vremenskim početkom niti je ovisno od nekog drugog, nego je 'apsolutno'? « (Zimmermann: TF, 248)

Tim pitanjem ovdje opet dolazimo do staroga Aristotelovog nauka o »negibljivom kretalu«, iz kojega je Toma, a s njim i skolastika, izvela dokaz o Bogu kao »neprouzročenom uzroku«, o netvarnom temelju materijalnoga svijeta, o njegovoj »jednostavnosti« nasuprot sastavljenosti vidljivoga svijeta, »osobnosti« itd. Cak i moja »razumna« egzistencija nužno upućuje na Boga s obzirom na to da prema Tomi (i Zimmermannu) »materija« ne može sama iz sebe poroditi duh, nego čovjeku duh biva »udahnut« činom rađanja, duh koji mu omogućuje da upravo temeljem te darovanosti i sam može doći na ideju o postojanju Boga te stoga težiti Njegovoj spoznaji. Dakle, naša vlastita razumnost nije za Zimmermanna ništa drugo doli puki »učinak« apsolutnoga uzroka razumne naravi, što bi - nasuprot Aristotelu - impliciralo puki emanacionizam novoplatonskoga tipa. Zimmermann je potpuno svjestan te opasnosti koja bi u jednome pogledu (kada se razumnost izvodi iz tvarnih procesa koji se događaju u mozgu) vodila u materijalizam i evolucionizam, a u drugome u »panteizam《 Božje sveprisutnosti u svijetu te time i »odgovornosti« za svo zlo koje se događa u njemu. Da bi se izbjegla ta dva stajališta Zimmermann se s Akvincem opredjeljuje za »metafizički dualizam« prema kojemu je

»... čitav svijet učinak apsolutnog osobnog bića ili Boga. I ja, kao dio svijeta, stojim u odnosu uzročnosti s Bogom: sav je moj život ovisan od Boga. Taj odnos čovjekova života s Bogom jest 'religija'.« (Zimmermann: TF, 249)

Ovo kauzalno tumačenje čovjekova odnosa s Bogom, koje Zimmermann naziva religija, potpuno isključuje čovjekovu slobodnu vjerničku odluku da se svojom vjerom »opredijeli« za Boga, a Božja ljubav prema stvorenju izražena u Kristovoj muci na Križu, su-patnja Boga sa svojim stvorenjem itd., nisu nikakva »tema« tako shvaćene »religije«: čovjek je svojom darovanom umnošću osuđen svoju egzistenciju ustrojiti religijski, tj. sub specie Boga, ${ }^{14}$ o kojemu je »ovisan«, pri čemu ta »ovisnost« isključuje svaku mogućnost »partnerstva«, na što danas poseban naglasak stavlja i katolička i protestantska teologija.

12

»Istinu znademo onda, kad mislimo u obliku sudova.« (Zimmermann: TF, 67)

13

»Metafizički su filozofi izgrađivali već Platon i Aristotel, a njihovim su putem u kršćanskoj eri nastavili sv. Augustin (354.-430.) i sv. Toma Akvinski (1225.-1274.), koji se smatraju prvacima skolastičke ili kršćanske filozofije. Ona se učila u kršćanskim školama, te ju je katolička Crkva usvojila kao osnovicu religije. Naročite su dvije nauke u ovoj metafizici, na koje se oslanja kršćanska religija, a to su teizam i psihološki spiritualizam, tj. učenja da postoji osobni Bog i da je duša čovjekova po duhovnoj naravi besmrtna. Dakle: Bog i duša, kako je već sv. Augustin izrekao, jest ono, što u prvom redu želi da spoznajno dohvati skolastička metafizika. Time je ova filozofija kao gotov sistem ušla u sferu kršćanske religije.« (Zimmermann: TF, 258)

14

To je po Zimmermannu »unutarnja teleologija č čjekova bića koja počiva na »zakonu voljne aktivnosti«, a dokaz toga je - u sferi ćudorednoga djelovanja - čovjekova sposobnost razlikovanja »dobra« i »zla«. Na ovu bismo tvrdnju mogli uzvratiti pitanjem: Zar prvi ljudi, Adam i Eva, nisu prognani iz Raja upravo zato što su jeli s drveta spoznaje (dobra i zla)? (Post 2,16); u čemu je teologija vi- 
To kršćansko razumijevanje bîti filozofije izražava se i u Zimmermannovom shvaćanju njezine zadaće davanja odgovora na $d v a$ temeljna pitanja: »1. koji je smisao života? i 2. koji je uzrok života - u čovjeku ili izvan njega?« (Zimmermann: TF, 293).

Pitanje o »smislu« čovjekove egzistencije za Zimmermanna je prije svega »kulturno« pitanje: opredjeljujući se za ovu ili onu ideju i na njoj zasnovane vrednote čovjek istodobno izgrađuje ne samo svoju kulturu nego i društvo u cjelini. To je za njega temeljno etičko pitanje, pitanje o vrijednosnome ustrojstvu čovjekova samorazumijevanja (orijentiranja) u svijetu i odnosa prema svemu što susreće u svijetu. No kreposno djelovati može po Zimmermannu samo onaj »tko je orijentiran o u z r o k u života« (Zimmermann: TF, 294), čime se bavi metafizika, što znači da Zimmermann u temelj čovjekova ćudorednog djelovanja postavlja metafizičko uvjerenje o »prekosvjetnom « uzroku svega postojećega, zbog čega metafizika dobiva prvenstvo pred etikom, Apsolut pred Bližnjim, a transcendencija pred imanencijom. Time se u potpunosti ruši suvremena zgrada novovjekovne subjektivnosti i teorija »slobode volje«, bez koje je cjelokupna filozofija XX. stoljeća nezamisliva. Bez »autonomije volje« nema slobode, a onda nema ni »slobodne odluke«, u Zimmermannovu slučaju, »Za« ili »Protiv« Boga, tj. nema slobodne vjerničke egzistencije, nego je sve prouzročeno i proviđeno.

Upravo osvjetljavanje te »prouzročenosti« i »proviđenosti« čini posljednju i najvišu zadaću filozofije koja više nije njezino »vrijeme sažeto u mislima« (Hegel), nego je događanje prisutnosti božanskoga u svijetu, povijesti i svakoj individualnoj egzistenciji koja ima jedino zadaću steći strogo znanstvenim putem svijest o toj prisutnosti. Znanstvenost takvoga postupka sastoji se, prema Zimmermannu, u zdravorazumskome uvidu da sve što se događa u svijetu mora imati svoj uzrok, a osvjetljavanje tih uzroka predstavlja za njega »konstrukciju nauke« ili, točnije, samostalnost i osebujnost svake znanosti:

»... dolazi do izražaja ne samo u rasporedu cjeline, u povezivanju problemâ, u opravdanju problemskog rješenja, nego i u pojedinim izrekama, koje su izraz određenog gledišta u zamršenom vrtlogu naziranja.« (Zimmermann: TF, 297)

Pozivajući se na kardinala Merciera, Zimmermann, što je bitno, želi istaknuti da cilj njegovih filozofskih istraživanja i bavljenja filozofijom uopće nije nikakva »apologetika i vjerska propaganda $\ll,{ }^{15}$ no - pođemo li od njegovih ranijih tvrdnji - teško se možemo oteti takvome dojmu zato što Zimmermann, ma koliko to nijekao, u svom znanstvenom pristupu filozofiji i znanosti uopće koristi gotovo isključivo (u bilješki upravo navedene) neoskolastičke autoritete, na kojima uopće i počiva njegova »kritika«, što dakako nema nikakve veze s Kantovim shvaćanjem »kritike«.

Drugi mu je »autoritet« prirodoznanstvena spoznaja $» 2 \times 2=4$ «, što stalno koristi i što stalno prigovara Kantu, čime bi i filozofski govor o Bogu morao podlijegati takvoj aksiomatici. Zimmermann uopće ne uviđa da matematska očevidnost nije isto što i empirijska očevidnost kao što ni vjerska očevidnost nije isto što i filozofska očevidnost! Ako bi te očevidnosti bile apsolutno identične, onda bismo iz očevidnosti Boga mogli izvesti svaku drugu, bilo prirodoznanstvenu ili filozofsku očevidnost i na njoj počivajuću »istinu«. Tu se očito previđa da matematski sud $» 2 \times 2=4$ « nije po sebi niti istinit niti neistinit: on postaje jednim ili drugim tek kada ga primijenimo na stvarne odnose, ${ }^{16}$ zbog čega se onda, suprotno Zimmermannu, može postaviti opravdano pitanje: Kako Boga kao vjersku očevidnost smjestiti u stvarne relacije kao neki »opaženi objekt«, a da ga se time ne sroza na razinu bilo kojeg stvo- 
renog bića u svijetu, čime bi se transcendencija potpuno ukinula u imanenciji tih stvarnih (svjesnih) relacija, odnosno sam Bog sveo bi se u sferu »čistoga razuma«. Zbog toga Zimmermann također griješi kada govori o kategoriji »različitosti« koja nije zamisliva bez članova relacije. Najproblematičnije je to što Zimmermann smatra da

»... u tom pojmu nije uključeno nikoje pojedinačno obilježje ove ili one različnosti između ovog ili onog objekta, pa je zato pojmovni sadržaj, kažemo, apstrahiran od pojedinačnosti. Utoliko se on razlikuje od pojedinačno shvaćenih različitosti; mi poimamo različnost uopće, tj. imamo o njoj općeniti pojam.« (Zimmermann: TF, 73)

Upravo obratno: općeniti pojam različitosti imamo tek zahvaljujući zbiljskoj zamjedbi različitosti, inače je ona potpuna fikcija i nikada se ne koristi bez navođenja toga zbiljskog odnosa. Jer kada Zimmermann kaže: »Relacija različnosti služi nam dakle za objektivnu valjanost sudova o opaženim objektima« (Zimmermann: TF, 72-73), on tada niječe da toj »relaciji različnosti« uopće prethodi zbiljska relacija različitosti te da je ona - $u$ sudu - samo njezin puki (logički) izraz i ništa više od toga. Ta redukcija bitka na sud, koja je posvuda prisutna u neoskolastičkoj filozofiji, želi potpuno isključiti sudećega subjekta i njegov »egzistencijalni« status, pri čemu onda Zimmermann zaboravlja da jedan takav, bez subjekta suđenja doneseni sud, nema nikakva smisla niti značajnosti za njegovu egzistenciju zato što ne izvire iz nje niti je uopće usmjeren na nju te zato ne može ništa ni izricati o njoj. Logičko suđenje nije spoznavanje zbiljskoga svijeta $i$ zbiljskih odnosa unutar njega. Ono je čisto misaona »operacija« koja podliježe vlastitim zakonitostima koje ne moraju podlijegati nikakvoj empirijskoj provjeri, ali time ni zahtijevati nikakvu »istinitost« u smislu nečega što bi bilo (etički) obvezujuće za bilo koju egzistenciju. Nema istinitosti bez njezina pojavljivanja u egzistenciji! - to bi Zimmermann dobro morao znati kao vjernik i kršćanin jer je Krist svojim Križem svjedočio svoj navještaj, za koji nije potrebovao nikakve »silogizme« niti »suđenje«.

Ako je spoznaja istine neovisna o spoznavajućem i sudećem subjektu, ona onda nema nikakva značenja za samoga tog subjekta, on je ne može prihvatiti samo na temelju vjerovanja, nego upravo na temelju vlastita egzistencijalnog svjedočenja, inače se gubi »očevidnost« te spoznaje, odnosno njezina uvjerljivost koja doista može biti uvjerljiva tek kada dobije svoju egzistencijalnu potvrdu i obistinjenje. Ovdje je sada, zbog »objektivnosti«, na kojoj stalno inzistira Zimmermann, potrebno kritički mu uzvratiti iz same neoskolastičke perspektive da bismo mogli sagledati i sve njegove moguće propuste u njegovu shvaćanju filozofije, što ćemo učiniti putem analize nekih bitnih dijelova

djela čovjekovu izvornu »oholost«, odnosno pokušaj da se izjednači s Bogom? Doduše ni filozofi kao filozofi nisu ništa bolji: »... umjesto zbiljnosti postaviti ideju zbiljnosti, umjesto bitka duh, umjesto prirode povijest, umjesto povijesti Boga, umjesto Boga čovjeka i tako u beskonačnost $-\mathrm{i}$ onda iz te 'nove' postavke reinterpretirati cjelokupnu povijest filozofije kao da sve to oduvijek već nije bilo skupa u igri.« (Pavić: 1997, 15)

15

$»$ Kako su prema tim imenima [Mercier, Geyser, Gemelli, Fröbes, Lindworsky, dakle, sve neoskolastički mislioci! - Z. M.] bijedni pokušaji, koji bi u nemoćnom bijesu proti istini htjeli da filozofiju proglase vjerovanjem. Zar je intelektualizam - osnovica aristo- telovske psihologije o duši - neki Credo...?« (Zimmermann: TF, 298) Zimmermann ovim oštro reagira na kritički prikaz njegove knjige Duševni život od strane Zdenka Vernića koji - prema Zimmermannovu mišljenju - oštro napada i samu Akademiju kao nakladnika što se objavljivanjem te knjige »ogriješila o znanstvenu slobodu savjesti i interkonfesionalni takt« (usp. Zimmermann: TF, 298 b).

16

Ivan Devčić objašnjava da taj matematski primjer Zimmermann uzima da bi pokazao da taj sud »ne ovisi o volji subjekta, nego o nužnim odnosima među brojkama«, čime se dokazuje »objektivnost logičkih (spoznajnih) načela« (Devčić: 2002, 41). 
iz knjige glasovitoga isusovačkog filozofa Johannesa Baptiste Lotza koji sebe smatra pripadnikom »Maréchalove« i istodobno »Heideggerove« škole (E. Coreth).

U 14. poglavlju svoje knjige, pod naslovom »Je li moguća kršćanska filozofija egzistencije«, Lotz ustvrđuje da danas mnogi katolički i nekatolički mislioci negiraju takvu mogućnost, u našoj svezi posebice izrijekom i S. Zimmermann (dovoljno je samo usporediti njegovu objavljenu knjigu o Jaspersu - Zimmermann: 2002). U toj svezi Lotz ističe da je »egzistencijalizam《 J.-P. Sartrea $^{17}$

»... ateističan i time izričito antikršćanski. Od toga se, doduše, bitno razlikuje Jaspers tako što na svoj način uvodi Boga u filozofiju egzistencije, i on se sve odlučnije odvaja od kršćanstva. Što se tiče Heideggera, on boravi kod bitka, ali ostavlja otvorenim pitanje o Bogu te posebice o kršćanskome Bogu.« (Lotz: 1965, 299) ${ }^{18}$

Afirmativni odnos prema mogućnosti kršćanske filozofije Lotz nalazi kod Gabriela Marcela, no s onu stranu te dileme Lotz ističe da su oba ta stava usko povezana s temeljnim nastojanjem »filozofije egzistencije«, a to je prema njegovu mišljenju »spašavanje čovjeka« od rastvaranja njegove supstancije, od »otuđenja«, »diktature mase« i potpune ugroženosti svih negativnim posljedicama tehničko-znanstvenoga svijeta.

Veliku zaslugu »filozofije egzistencije« Lotz vidi prije svega u tomu što čovjeka promatra kao »egzistenciju«:

»... on [čovjek] - i to jedino on - zove se egzistencija ako na temelju vlastite odluke raspolaže samim sobom, ako iz dubine svoje slobode oblikuje svoj život. On ne raste prirodnom samorazumljivošću poput biljke i životinje, nego do ozbiljenja samoga sebe dolazi slobodnim izborom kojim se odlučuje za samoga sebe.« (Lotz: 1965, 301)

Ta zasnovanost na samome sebi, »odluka« iz samoga sebe za samoga sebe, omogućuje egzistenciji da transcendira svaki predmetno uvjetovani način bitka-u-svijetu, da se ne osjeća otrgnutim i odvojenim od svojega Temelja, Boga, kako tvrdi francuski »egzistencijalizam«, nego da upravo zahvaljujući tom nepredmetnom (smislenom) odnosu prema bitku bića u cjelini istodobno transcendira »u prostor božanskoga«, čime se prema Lotzu otvara najširi mogući horizont slobode u međuodnošenju egzistencije i transcendencije, a ne da je egzistencija - kao kod Zimmermanna - ovisna o transcendenciji. Utoliko »religio《 smijemo razumjeti i kao čovjekov »uspon«, tj. kao njegovo samoprevladavanje u onom postalom jer tu čovjek-vjernik neprestano »nadmašuje« sebe, otvara samome sebi nove mogućnosti bitka potpuno svjestan da u božanskim stvarima nije u posjedu nikakva apodiktičnoga znanja, što je sa sv. Pavlom izvrsno pokazao Martin Heidegger: raspet između svojega povijesnoga fakticiteta (postalosti) i zahtjeva za njegovim radikalnim napuštanjem, čovjek poput apostola Pavla stoji pred dvostrukom mogućnošću: ili izgubiti sebe u bavljenju svagdanjim stvarima ili se radikaliziranjem pitanja o smislu vlastita bitka uzdići do horizonta na kojemu nas u obliku pitanja susreće naša vlastita egzistencija.

»Taj se prostor otvara najprije kao Drugo (das Andere) u odnosu na svako unutarsvjetovno biće kao Ne-biće ili Ništa. U njemu se skriva i ujedno pokazuje bitak koji leži u temelju svakoga bića, bitak koji ga nosi koji se pojavljuje kao ono bezgranično i bezuvjetno. Odatle, konačno, put vodi k subsistirajućem bitku, k Apsolutu-naprosto ili k Bogu. Više nego samo punktualno, trenutačno biće ili zbiljski čovjek, čovjek može biti samo tako što unutarsvjetovno biće uvijek već susreće u prostoru onoga, naposljetku nadsvjetovnog bitka.« (Lotz: 1965, 302)

Kada Heidegger kaže da nam se »bitak daje (ergibt) iz Ništa«, tada to za Lotza znači da to »Ništa« kao horizont čistog nepredmetnog iskustva, unutar kojega 
se uopće može uspostaviti egzistencijalno-smisleni odnos s Bogom, nakon čega i sam vjernik može - povratno - iskušavati svijet upravo u horizontu toga »odnosa«. Ništa od takvoga (spo)razumijevanja nemamo kod Zimmermanna zato što je njemu svaka pomisao na egzistenciju, koja se zasniva na samoj sebi, već unaprijed ateistična, a spoznaja Boga moguća i samo zahvaljujući »ovisnosti o Bogu«, zbog čega je nezamisliva bilo kakva slobodna odluka za Boga kao Ništa, iz kojega tek izrasta pravo iskustvo bitka. Upravo zbog toga Zimmermann u svom prikazu nije mogao niti htio čuti Drugoga, naime moguće protuargumente iz tabora filozofije egzistencije:

»Monološki ton, koji često odzvanja Zimmermannovim interpretacijama, nije dopustio da se čuje glas Drugoga, a time niti to da nešto važi protiv njega, odnosno protiv njegova vlastite filozofske pozicije.« (Pavić: 2002, 122)

\section{Literatura}

Brajičić, R. (1995): »Kantov promašaj cilja«, u: Josipović, M., Zovkić, M. (prir.), Crtajte granice - ne precrtajte ljude. Zbornik radova u povodu imenovanja vrhbosanskog nadbiskupa Vinka Puljića Kardinalom, VVTŠ, Sarajevo, Bol.

Brajičić, R. (1996): Filozofski eksperiment. Signifikantni i egzistentni vidici u filozofiji, Hrvatsko filozofsko društvo, Zagreb.

Cramer, W. (1967): Gottesbeweise und ihre Kritik. Prüfung ihrer Beweiskraft, Klostermann, Frankfurt am Main.

Čehok, I. (1993): Filozofija Stjepana Zimmermanna, Hrvatsko filozofsko društvo, Zagreb.

Čehok, I. (1995): »Stjepan Zimmermann«, u: Zenko, F. (prir.), Novija hrvatska filozofija (Hrestomatija filozofije, sv. 10), Školska knjiga, Zagreb.

Devčić, I. (2002): »Zimmermannovo opravdanje racionalne metafizike«, u: Oslić, J., Pavić, Ž. (ur.), Život i djelo Stjepana Zimmermana. Zbornik radova sa znanstvenog skupa održanog 5. listopada 2000. u Hrvatskoj akademiji znanosti i umjetnosti, Hrvatska akademija znanosti i umjetnosti - Razred za društvene znanosti, Katolički bogoslovni fakultet, Zagreb.

Drežnjak, T. (2014): »Hrvatski neoskolastici protiv velikih ideologija 20. stoljeća - S. Zimmermann i H. Bošković«, u: Šestak, I., Oslić, J., Gavrić, A. (ur.), Prilozi o hrvatskoj neoskolastici, Filozofsko-teološki institut Družbe Isusove, Zagreb.

Elders, L. J. (1985): Die Metaphysik des Thomas von Aquin in historischer Perspektive, I. Teil: Das ens commune, Anton Pustet, Salzburg, München.

Elder, L. J. (1987): Die Metaphysik des Thomas von Aquin in historischer Perspektive, II. Teil: Philosophische Theologie, Anton Pustet, Salzburg, München.

Gruber, C. (1880): Kršćanska filozofija u duhu angjeoskoga naučitelja sv. Tome Akvinjanina obzirom na najnoviju encikliku Aeterni Patris, Zagreb.

Heidegger, M. (1984): Sein und Zeit, Max Niemeyer Verlag, Tübingen.

Heidegger, M. (2004): Fenomenologija religioznog života, Demetra, Zagreb.

Husserl, E. (1962): Die Krisis der europäischen Wissenschaften und transzendentale Phänomenologie, u: Biemel, W. (ur.), Gesammelte Werke. Husserliana 6, Martinus Nijhoff, Den Haag. [Hua VI]

Josipović, M. (2010): Philosophia perennis, Naklada Breza, Zagreb.

17

Već smo ukazali da Zimmermann uopće ne pravi razliku između francuskoga »egzistencijalizma« i njemačke »filozofije egzistencije $\ll$ !
18

Usp. o tomu Heideggerova rana predavanja o religiji i faktičnom iskustvu vjere u Heidegger: 2004. O tomu također Pavić: 1997, posebice $\S 2.2 .2$ i 2.2 .3 . 
Kant, I. (1993): Kritik der reinen Vernunft, Schmidt, R. (ur.), Felix Meiner Verlag, Hamburg. [KdrV]

Kant, I. (1993): Kritik der praktischen Vernunft, Vorländer, K. (ur.), Felix Meiner Verlag, Hamburg. [KdpV]

Kusić, A. (2002): »Počeci razvoja problema noetike u filozofiji S. Zimmermanna«, u: Oslić, J., Pavić, Ž. (ur.), Život i djelo Stjepana Zimmermana. Zbornik radova sa znanstvenog skupa održanog 5. listopada 2000. u Hrvatskoj akademiji znanosti i umjetnosti, Hrvatska akademija znanosti i umjetnosti - Razred za društvene znanosti, Katolički bogoslovni fakultet, Zagreb.

Papa Lav XIII. (2015): Aeterni Patris. Dostupno na: http://www.stjosef.at/dokumente/aeterni patris.htm (pristupljeno 15. 12. 2015.).

Lotz, J. B. (1965): Sein und Existenz. Kritische Studien in systematischer Absicht, Herder Verlag, Freiburg, Basel, Wien.

Lovrić, M. (2014): »Zimmermannova kritika Kantova subjektivizma«, u: Šestak, I., Oslić, J., Gavrić, A. (ur.), Prilozi o hrvatskoj neoskolastici, Filozofsko-teološki institut Družbe Isusove, Zagreb.

Muck, O. (1988): »Die deutschsprachige Maréchal-Schule - Transzendentalphilosophie als Metaphysik: J. B. Lotz, K. Rahner, W. Brugger, E. Coreth u.a.«, u: Coreth, E., Neidl, W. M., Pfligersdorffer, G. (ur.), Christliche Philosophie im katholischen Denken des 19. und 20. Jahrhunderts, Bd. 2: Rückgriff auf scholastische Erbe, Styria, Graz, Wien, Köln.

Oslić, J. (2004): Vjera i um. Neoskolastički i suvremeni pristupi, Hrvatsko filozofsko društvo, Zagreb.

Oslić, J., Pavić, Ž. (ur.): Život i djelo Stjepana Zimmermanna. Zbornik radova sa znanstvenog skupa održanog 5. listopada 2000. u Hrvatskoj akademiji znanosti i umjetnosti, Hrvatska akademija znanosti i umjetnosti - Razred za društvene znanosti, Katolički bogoslovni fakultet, Zagreb 2002.

Pavić, Ž. (1997): Metafizika i hermeneutika, Hrvatsko filozofsko društvo, Zagreb.

Pavić, Ž. (2002): »Čovjekovo opstojanje između egzistencije i transcendencije. Zimmermannova rasprava s filozofijom egzistencije K. Jaspersa«, u: Oslić, J., Pavić, Ž. (ur.), Život $i$ djelo Stjepana Zimmermana. Zbornik radova sa znanstvenog skupa održanog 5. listopada 2000. u Hrvatskoj akademiji znanosti $i$ umjetnosti, Hrvatska akademija znanosti i umjetnosti - Razred za društvene znanosti, Katolički bogoslovni fakultet, Zagreb.

Pavić, Ž. (2006): Philosophia fundamentalis Josipa Stadlera, Vrhbosanska katolička teologija, Sarajevo.

Pavić, Ž. (2007): »Neoskolastika 20. stoljeća u Hrvatskoj i Bosni i Hercegovini«, u: Barbarić, D., Bracanović, T. (ur.), Hrvatska filozofija u XX. stoljeću, Matica hrvatska, Zagreb.

Pavić, Ž. (2009): Arhonti bitka. Pokus filozofije vjere, Ex Libris, Rijeka.

Pažanin, A. (1968): Znanstvenost i povijesnost u filozofiji Edmunda Husserla, Naprijed, Zagreb.

Simon, J. (1974): »Sprachphilosophische Aspekte der neueren Philosophiegeschichte«, u: Simon, J. (ur.), Aspekte und Probleme der Sprachphilosophie, Alber Verlag, Freiburg, München.

Weischedel, W. (1972): Gott der Philosophen, Wissenschaftliche Buchgesellschaft, Darmstadt.

Zimmermann, S. (1929): Filozofija u Hrvatskoj zastupana po svećeničkom staležu - kroz tisuću godina, Hrvatska bogoslovna akademija, Zagreb.

Zimmermann, S. (1934): Temelji filozofije. Historijsko-kritička orijentacija, Matica hrvatska, Zagreb. [TF]

Zimmerman, S. (2002): Jaspersov egzistencijalizam. Sv. 1: Karl Jaspers prema religiji. Fragmenti o Jaspersovom egzistencijalizmu s općom filozofijom, napose neoskolastičkom, Hrvatska akademija znanosti i umjetnosti, Zagreb. 


\section{Zvonko Miličić}

\section{Stjepan Zimmermann: \\ Die Grundlagen der (vorkantischen) Philosophie}

\section{Zusammenfassung}

Obwohl sich Stjepan Zimmermann zeit seines Lebens mit der noetischen Problematik beschäftigt hat, versucht man in diesem Beitrag - ausgehend von seinem Werk Die Grundlagen der Philosophie (Temelji filozofije) aus dem Jahr 1934 - die Frage zu beantworten: Was Zimmermann unter der „Philosophie“ überhaupt versteht, welche „Fundamenten“, den „Sinn" und die Tragweite sie überhaupt hat? Trotz seines Versuchs, die Philosophie „noetisch" zu begründen, geht er über ihr scholastisch-neuscholastisches Verständnis als die „Theodizee“, als die Berechtigung Gottes in der Geschichte nicht hinüber, womit sich eher Philosophie, als Theologie beschäftigt.

\section{Schlüsselwörter}

„Ding an sich“, Gott, Glaube, philosophischer Glaube, Transzendenz, Existenz, gegenwärtige Existenzphilosophie-Neuscholastik 